Premiere Educandum: Jurnal Pendidikan Dasar dan Pembelajaran

Volume 10 (2) 215 - 226 Desember 2020

ISSN: 2088-5350 (Print) / ISSN: 2528-5173 (Online)

Doi: $10.25273 /$ pe.v10i2.6384

The article is published with Open Access at: http://e-journal.unipma.ac.id/index.php/PE

\title{
Pengembangan media komik komsa materi rangka pada pembelajaran IPA di sekolah dasar
}

\author{
Anggit Grahito Wicaksono $\bowtie$, Universitas Slamet Riyadi \\ Jumanto, Universitas Slamet Riyadi \\ Oka Irmade, Universitas Slamet Riyadi
}

$\triangle$ anggitgrahito@unisri.ac.id

\begin{abstract}
The TIMSS survey results provide an overview of the low science achievement of students in Indonesia so it is necessary to improve the quality of learning, especially science. The purpose of this research was (1) to find out the obstacles faced by teachers in the use of science learning media in SD Negeri Pajang 1 Surakarta, (2) formulating learning media designs that are suitable for use in science learning at SD Negeri Pajang 1 Surakarta, and developing comic learning media called "KOMSA" in human skeleton subject for science learning. The method used in this research is Research and Development through a modified Plomp model by eliminating the implementation phase. The results of the research obtained are (1) the use of learning media is not optimal, (2) the design of learning media is the contextual based comics media, and the results are products of prototype comic media learning called "KOMSA" in human skeleton subject. Recommendations for future researchers can develop comic media "KOMSA" for other subject matter that is abstract and difficult for students to understand. This research has implications for the development of comic media in various learning frameworks.
\end{abstract}

Keywords: Learning Media, Comic, Science Learning

Abstrak: Hasil survei TIMSS memberikan gambaran tentang rendahnya prestasi IPA siswa yang ada di Indonesia sehingga perlu dilakukan peningkatan kualitas pembelajaran khususnya IPA. Tujuan dari penelitian ini adalah (1) untuk mengetahui kendala yang dihadapi oleh guru dalam penggunaan media pembelajaran sains di SD Negeri Pajang 1 Surakarta, (2) merumuskan desain media pembelajaran yang cocok untuk digunakan dalam pembelajaran IPA di SD Negeri Pajang 1 Surakarta, dan mengembangkan media pembelajaran komik yang disebut "KOMSA" dalam materi rangka untuk pembelajaran IPA. Metode yang digunakan dalam penelitian ini adalah Penelitian dan Pengembangan melalui model Plomp yang dimodifikasi dengan menghilangkan fase implementasi. Hasil penelitian yang diperoleh adalah (1) penggunaan media pembelajaran yang belum optimal, (2) desain pembelajaran media adalah media komik berbasis kontekstual, dan hasilnya adalah produk prototype media pembelajaran komik yang disebut "KOMSA" pada materi rangka. Rekomendasi untuk peneliti selanjutnya dapat mengembangkan media komik "KOMSA" untuk materi pelajaran lain yang bersifat abstrak dan sulit dipahami oleh siswa. Penelitian ini berimplikasi pada pengembangan media komik dalam berbagai kerangka pembelajaran.

Kata kunci: Media Pembelajaran, Komik, Pembelajaran IPA

Received 02 May 2020; Accepted 18 November 2020; Published 01 December 2020

Citation: Wicaksono, A.G., Jumanto, \& Irmade, O. (2020). Pengembangan media komik komsa materi rangka pada pembelajaran IPA di sekolah dasar. Premiere Educandum : Jurnal Pendidikan Dasar dan Pembelajaran, 10(2), 215 - 226. Doi.org/10.25273/pe.v10i2.6384

\section{(c) BY-NC-SA}

Copyright (C2020 Premiere Educandum : Jurnal Pendidikan Dasar dan Pembelajaran

Published by Universitas PGRI Madiun. This work is licensed under the Creative Commons Attribution-NonCommercial-

ShareAlike 4.0 International License. 


\section{PENDAHULUAN}

Hasil survei Trends in Student Achievement in Mathematics and Science (TIMSS) menunjukkan bahwa terdapat masalah pendidikan di Indonesia, terutama pada bidang IPA. TIMSS adalah studi internasional yang mengukur kemampuan siswa di bidang Matematika dan Sains yang diinisiasi oleh the International Association for the Evaluation of Educational Achievement (IEA) (Kemdikbud, 2016). TIMSS merupakan studi yang diselenggarakan setiap empat tahun sekali. Pada TIMSS 2015, target populasi siswa Indonesia adalah siswa kelas 4 sekolah dasar untuk mengukur capaian Matematika dan Sains siswa SD/MI pada studi internasional (Hadi \& Novaliyosi, 2019). Indonesia berada di posisi bawah jika dibandingkan dengan beberapa negara di Asia. Nilai skor IPA menurut survei dari TIMSS yaitu tahun 2007, 2011, dan 2015 secara berurutan adalah 427, 406, dan 397. Perolehan skor Sains (IPA) tersebut menempatkan Indonesia pada peringkat 35 dari 49 (2007), peringkat 39 dari 42 negara (2011), dan peringkat 45 dari 48 negara (2015) (Hadi \& Novaliyosi, 2019). Hasil survei dari TIMSS tersebut menunjukkan rendahnya prestasi IPA siswa yang ada di Indonesia sehingga perlu adanya perbaikan kualitas pembelajaran khususnya IPA di Indonesia.

Permasalahan yang sama ditemukan pada observasi awal yang dilakukan di SD Negeri Pajang I Surakarta ke beberapa siswa kelas IV, rata-rata mereka kesulitan dalam pembelajaran IPA terutama pada materi rangka, dari hasil ulangan harian pada tanggal 7 Juni 2020 pada materi rangka hampir 50\% siswa yang belum mencapai batas KKM, kesulitan ini dikarenakan memang beberapa materi dalam pelajaran IPA tergolong materi yang sulit dan kurang menarik untuk dipelajari. Hal ini juga didukung dengan hasil wawancara awal pada tanggal 16 Juni 2020 dengan guru kelas IV di SD Negeri Pajang I Surakarta yang menerangkan bahwa materi pelajaran IPA terkesan rumit dan kurang menarik bagi siswa, karena sebagian besar pembelajaran pada materi ini dilaksanakan dengan mengacu pada buku teks pelajaran saja sehingga minat siswa dalam belajar kurang. Karena pada proses pembelajaran peran guru dalam menyampaikan materi kurang maksimal, ini juga berpengaruh besar terhadap keberhasilan belajar siswa, maka dari itu inovasi dalam pembelajaran sangat diperlukan baik dalam pemilihan model, metode dan media pembelajaran (Baharun, 2016; Mahnun, 2012). Pada kenyataanya banyak siswa yang merasa kurang tertarik dengan buku teks yang disediakan di sekolah yang sifatnya lebih formal sehingga siswa enggan untuk membacanya maupun mempelajarinya. Dengan masalah seperti ini, berdampak pada hasil belajar siswa yang belum optimal, karena minat mereka dalam membaca buku teks pelajaran IPA kurang. Kecenderungan yang ada siswa tidak menyukai buku-buku teks apalagi yang tidak disertai gambar dan ilustrasi menarik (Daryanto, 2013; Nugraheni, 2017).

Salah satu media baca yang cukup inovatif dan menarik bagi siswa untuk pembelajaran IPA adalah media komik. Media adalah segala sesuatu yang dapat digunakan untuk mengirim semua pesan dari pengirim ke penerima, sehingga dapat merangsang pikiran, perasaan, perhatian pelajar, minat dan perhatian, sehingga proses pembelajaran dapat berlangsung (Arsyad, 2011; Trisiana et al., 2020). Media pembelajaran dapat dipahami sebagai media yang digunakan dalam proses dan tujuan pembelajaran (Miftah, 2013; Trisiana et al., 2020). Fungsi media dalam proses pembelajaran sebagai berikut: (a) memperjelas penyajian pesan dan informasi sehingga dapat memperlancar dan meningkatakan proses kegiatan yang dilakukan oleh guru kepada peserta didik; (b) meningkatkan dan mengarahkan anak sehingga dapat menimbukan keinginan mengikuti kegiatan, interaksi yang lebih langsung antar anak dan lingkunganya; (c) mengatasi keterbatasan indra, ruang, dan waktu, anak dapat melihat objek tanpa harus berada ditempat sebenarnya (Arsyad, 2011; Sadiman, 2014).

Komik merupakan salah satu media visual yang dirancang sebagai media pembelajaran yang memiliki kelebihan-kelebihan yang sulit didapatkan dari media lain. 
Kelebihan itu diantaranya mampu mendukung perkembangan imajinasi siswa, penggunaan ilustrasi dalam komik dapat meningkatkan kemampuan analisis siswa dan menemukan informasi yang terdapat didalamnya (Daryanto, 2013). Kelebihan lain media komik dapat merangsang minat siswa dalam mempelajari materi yang disajikan dalam komik sehingga siswa menjadi lebih tertarik (Negara, 2014; Pratiwi \& Kurniawan, 2013). Media gambar dapat menyalurkan energi dikarenakan gambar dapat menambah ragam baru dan mendorong siswa terlibat total dengan pengalaman belajarnya. Komik memang sudah cukup banyak beredar di pasaran, tetapi komik untuk media pembelajaran IPA masih minim. Komik diharapkan berfungsi sebagai media pembelajaran mandiri karena siswa dapat menemukan sendiri konsep IPA yang dimaksud dengan atau tanpa bantuan guru (Wahyuningsih, 2012). Konsep tersebut akan bertahan lama dalam ingatan siswa karena konsep tersebut ditemukan dan disimpulkan sendiri oleh siswa. Hakikat IPA sebagai produk ilmiah berisi kumpulan pengetahuan, IPA sebagai proses ilmiah mengacu pada cara menginvestigasi suatu masalah menggunakan keterampilan proses sains (metode ilmiah), IPA sebagai sikap ilmiah mengacu pada cara mengembangkan kemampuan berpikir, dan IPA sebagai aplikasi adalah penggunaan konsep-konsep abstrak yang dapat dimanifestasikan dalam bentuk-bentuk spesifik maupun teknologi (Chiappetta \& Koballa, 2010). Pembelajaran IPA adalah proses yang dapat membantu siswa belajar lebih bermakna melalui keterampilan proses sehingga mereka dapat menguasai pengetahuan ilmiah dan hukum alam serta menerapkannya dalam konteks kehidupan nyata (Wicaksono, 2020). Selain itu, media komik ini dapat meningkatkan daya pikir visual siswa sekaligus sebagai media hiburan (Novianti \& Syaichudin, 2015). Media komik dapat memotivasi siswa untuk belajar IPA dibandingkan media buku teks pelajaran IPA yang tersedia (Widyawati \& Prodjosantoso, 2015). Media komik ini dikembangkan berbasis pendekatan kontekstual. Pendekatan kontekstual pada media komik dapat mendorong siswa dalam membuat hubungan antara pengetahuan yang telah dimiliki dengan penerapannya dalam kehidupan mereka sehari-hari. Proses pembelajaran kontekstual akan mengkonstruksi pengetahuan dan keterampilan siswa sendiri sesuai dengan prinsip konstruktivisme (Hidayat, 2012; Ramdani, 2018).

Penelitian sebelumnya yang telah dilakukan oleh Wicaksono et. al (2017) menunjukkan bahwa penggunaan media komik KOMSA (Komik Sains) berbasis kontekstual dalam meningkatkan hasil belajar kognitif serta memiliki keefektifan dalam kriteria sedang. Hal ini sejalan dengan pendapat Puspitorini (2014) dalam penelitiannya menyimpulkan bahwa media komik mampu meningkatkan motivasi, hasil belajar kognitif, dan hasil belajar afektif. Penelitian sejenis yang membahas tentang komik oleh Avrilliyanti et al. (2013) menunjukkan bahwa penggunaan media komik pada pembelajaran Sains (Fisika) lebih baik daripada penggunaan media buku teks. Hasil-hasil penelitian tersebut mengungkapkan bahwa media komik adalah salah satu alternatif penyelesaian masalah dalam peningkatan hasil belajar IPA siswa di sekolah yang cukup efektif.

Hasil-hasil penelitian tersebut menunjukkan bahwa penggunaan komik berbasis kontekstual, dapat dijadikan sebagai inovasi dalam proses pembelajaran di sekolah, maka penelitian ini penting dilakukan. Komik yang sesuai dengan konteks kehidupan sehari-hari diharapkan dapat menjadikan materi sains sesuai dengan perkembangan dan pengalaman siswa sehingga siswa termotivasi untuk mempelajari dan memahami materi IPA yang akan berdampak pada hasil belajar kognitif siswa yang meningkat. Komik berbasis kontekstual ini dikembangkan dengan spesifikasi: komik berbasis kontekstual berbentuk comic book yang terdiri dari beberapa gambar beralur cerita dan memiliki muatan saintifik. Komik ini dikembangkan berdasarkan indikator dan kompetensi dasar pada materi rangka kelas IV dengan alur cerita yang berbeda dengan pengembangan komik KOMSA sebelumnya pada materi energi. Komik ini didesain sedemikian rupa sehingga mudah dipahami oleh siswa dan berkaitan dengan peristiwa yang terjadi dalam kehidupan sehari-hari. Komik berbasis kontekstual ini hanya media pembantu pembelajaran IPA bukan pengganti buku teks. Penelitian dengan pembuatan media komik ini bertujuan 
untuk (1) mengkaji kendala yang dihadapi guru dalam penggunaan media pembelajaran IPA di SD Negeri Pajang 1 Surakarta dan (2) memformulasikan desain media pembelajaran komik yang sesuai untuk digunakan dalam pembelajaran IPA di SD Negeri Pajang 1 Surakarta. Implikasi dari penelitian ini adalah pada pengembangan media komik dalam berbagai kerangka pembelajaran.

\section{METODE}

\section{Desain dan Prosedur Penelitian}

Metode penelitian yang digunakan adalah metode penelitian dan pengembangan atau dikenal dengan Research and Development (R\&D). Metode ini digunakan untuk menghasilkan produk tertentu dan menguji keefektifan produk tersebut (Haryati, 2012). Metode ini menggunakan model yang dikembangkan oleh Plomp et al. (2013) yang diadaptasi dengan sedikit modifikasi dengan menghilangkan fase implementation karena penelitian ini hanya dibatasi pada pengembangan produk saja sehingga menggunakan empat fase utama, yakni (1) preliminary investigation, (2) design, (3) realization/construction, dan (4) test, evaluation, and revision. Secara umum dapat ditunjukkan pada GAMBAR 1.

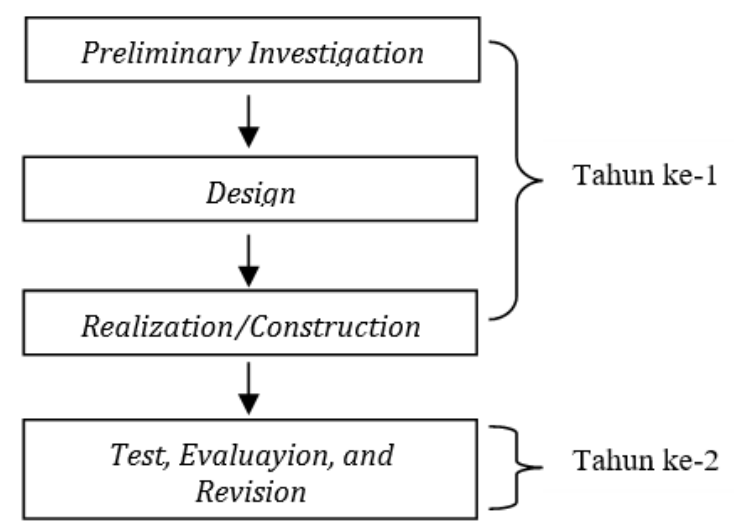

GAMBAR 1. Model plomp modifikasi

Fase/tahapan dari modifikasi model penelitian dan pengembangan Plomp et al. (2013) tersebut dapat diuraikan sebagai berikut: 1) Fase preliminary investigation (investigasi awal), fase dimana penyelidikan terhadap masalah-masalah yang muncul (definisi masalah/defining the problem). 2) Fase design (perancangan), fase ini mendesain pemecahan masalah yang dikemukakan pada fase investigasi awal. 3) Fase realization/construction (realisasi/konstruksi), pada fase ini desain direalisasikan dan dikonstruksi. 4) Fase test, evaluation, and revision (tes, evaluasi, dan revisi), fase ini solusi/pemecahan masalah diuji dan dievaluasi. Penelitian tahun pertama ini hanya melaksanakan fase yang pertama (preliminary investigation), fase kedua (design), dan fase ketiga (realization/construction). Pada fase preliminary investigation dibatasi pada analisis kebutuhan yang didasarkan dari observasi awal di lapangan dan wawancara awal yang dilakukan oleh dua peneliti selama bulan Juni 2018. Pada fase design, dilakukan perancangan pemecahan masalah yang dilakukan selama 3 bulan (Juli - September 2018) didasarkan dari hasil analisis kebutuhan pada fase preliminary investigation. Tahapantahapan pada fase perancangan ini yaitu pembuatan tokoh atau karakter dalam komik dan penyusunan storyboard media komik. Fase ini menggunakan pensil dan sketch book untuk membuat sketsa awal dalam storyboard. Fase berikutnya adalah realization/construction, fase ini adalah realisasi dan konstruksi dari fase design yang dilakukan selama 2 bulan (Oktober - Nopember 2020). Tahapan-tahapan pada fase realization/construction yaitu 
pembuatan sketsa komik manual, pengolahan sketsa komik dengan software Paint dan Photoshop, dan pewarnaan serta penyempurnaan komik menggunakan drawing pad.

\section{Subjek Penelitian}

Subjek yang digunakan dalam penelitian adalah seorang guru selaku wali kelas kelas IV SD Negeri Pajang I Surakarta. Subjek yang lain adalah empat orang siswa kelas IV SD Negeri Pajang I Surakarta terdiri dari 2 orang siswa perempuan dan 2 orang siswa laki-laki dengan tingkat kemampuan kognitif tinggi dan rendah khususnya dalam materi IPA.

\section{Instrumen Penelitian dan Indikator}

Instrumen penelitian yang digunakan dalam penelitian ini dapat dijabarkan dengan jelas pada TABEL 1.

TABEL 1. Instrumen Peneltian dan Indikator

\begin{tabular}{|c|c|c|c|c|c|}
\hline No & Jenis Data & Metode & Instrumen & Subjek & Indikator \\
\hline 1 & Analisis Kebutuhan & Wawancara & Pedoman & Guru dan & - Kondisi Pembelajaran \\
\hline & Media Pembelajaran & & Wawancara & Siswa & IPA \\
\hline & & & & & $\begin{array}{l}\text { - Media Pembelajaran } \\
\text { yang Diperlukan }\end{array}$ \\
\hline \multirow[t]{4}{*}{2} & Permasalahan dalam & Observasi & Lembar & Guru dan & - Kendala Pembelajaran \\
\hline & Pembelajaran IPA & & Observasi & Siswa & IPA \\
\hline & & & & & - Penggunaan Media \\
\hline & & & & & Pembelajaran IPA \\
\hline
\end{tabular}

\section{Analisis Data}

Teknik analisis data yang digunakan dalam penelitian ini adalah Teknik analisis data kualitatif. Data kualitatif dalam penelitian ini diperoleh dari hasil observasi dan wawancara. Analisis data dilakukan dengan mengorganisasikan data, menjabarkan ke dalam unit-unit, melakukan sintesa, menyusun ke dalam pola, memilih mana yang penting dan mana yang akan dipelajari, dan membuat kesimpulan. Data penelitian yang diperoleh selama proses penelitian dicatat kemudian dijabarkan secara deskriptif dan ditarik kesimpulan.

\section{HASIL PENELITIAN}

Hasil penelitian dan pengembangan media komik "KOMSA" materi rangka pada pembelajaran IPA diuraikan berdasarkan fase-fase penelitian dan pengembangan berdasarkan model Plomp dengan sedikit modifikasi menjadi empat fase utama yaitu: preliminary investigation, design, realization/construction, dan test, evaluation, and revision. Pada tahun pertama ini penelitian dan pengembangan hanya melakukan tiga fase saja. Hasil penelitian dan pengembangan media KOMSA melalui modifikasi model Plomp tersebut dapat dijabarkan sebagai berikut.

\section{Fase Preliminary Investigation (Investigasi Awal)}

Pada fase investigasi awal ini merupakan langkah untuk melakukan analisis kebutuhan dari berbagai masalah, potensi, dan kendala yang muncul dalam pembelajaran IPA. Pembelajaran IPA, khususnya pada materi rangka di SD Negeri Pajang I Surakarta masih menemui beberapa masalah dan kendala. Berdasarkan hasil observasi awal yang dilakukan di kelas IV SD Negeri Pajang I Surakarta sebanyak satu kelas terlihat bahwa kegiatan pembelajaran IPA yang dilakukan oleh guru masih kurang dalam penggunaan 
media pembelajaran. Pembelajaran sudah menggunakan media pembelajaran berupa rangka tubuh manusia dan magnet, namun media yang telah digunakan tersebut adalah media yang belum kontekstual dan belum mudah dipahami oleh siswa. Media pembelajaran tersebut kurang menarik bagi siswa karena sudah biasa dan tidak memiliki inovasi yang signifikan. Menurut hasil wawancara dengan 4 siswa kelas 4 yang terdiri dari 2 orang siswa perempuan dan 2 orang siswa laki-laki di SD Negeri Pajang I Surakarta 75\% siswa tidak menyukai pembelajaran IPA karena materinya cenderung banyak hafalan dan susah dibayangkan atau abstrak bagi siswa. Kondisi ini memerlukan adanya media pembelajaran yang dapat digunakan untuk mewujudkan konsep yang abstrak menjadi lebih konkret. Salah satu media yang dapat mewakili adalah media komik. Hal tersebut didukung dengan hasil wawancara dengan 4 orang siswa kelas IV SD Negeri Pajang I Surakarta yang dipilih secara acak, dimana $75 \%$ siswa dengan 2 orang siswa laki-laki dan 1 orang siswa perempuan sangat menyukai komik sedangkan 1 orang siswa perempuan tidak menyukai komik karena belum pernah membaca komik.

Hasil wawancara dengan satu orang guru kelas IV SD Negeri Pajang I Surakarta, mengungkapkan bahwa nilai muatan IPA siswa masih kurang memuaskan. Hasil tersebut menjadi indikator bahwa pembelajaran IPA saat ini belum dapat dimengerti dengan optimal oleh siswa. Siswa merasa kesulitan dalam memahami konsep dan pengetahuan tentang IPA salah satunya karena buku teks dan media pembelajaran yang digunakan oleh guru masih belum bisa mengatasi permasalahan tersebut. Materi yang disajikan dalam buku teks sangat monoton, bahasa yang digunakan sangat formal, dan sulit dimengerti oleh siswa, sehingga siswa kurang tertarik untuk membaca buku teks tersebut. Media pembelajaran yang telah digunakan guru masih sangat konvensional tanpa ada inovasi baru yang menarik dan kurang dapat membantu dalam pembelajaran. Pengembangan komik sebagai media pembelajaran IPA khususnya materi rangka sangat diperlukan dalam proses pembelajaran IPA di SD Negeri Pajang I Surakarta.

\section{Fase Design (Desain)}

Pembuatan desain komik dilakukan oleh dua peneliti diawali dengan menentukan judul yang tepat untuk komik dan ditentukan judul tersebut adalah "KOMSA" yang merupakan akronim dari Komik Sains. Setelah selesai langkah berikutnya adalah membuat tokoh dan karakter utama dalam komik ini. Ada tiga tokoh utama dalam komik yaitu Komar, Santi, dan Ayah. Komar sebagai tokoh utama dalam komik ini memiliki karakter semangat, hiperaktif, badung, sangat suka bermain game dan malas belajar. Santi merupakan adik komar memiliki karakter rajin belajar, selalu juara kelas, cengeng, dan sangat manja. Tokoh utama yang terakhir, Ayah memiliki karakter bijaksana, tidak banyak bicara, dan sayang keluarga. Langkah berikutnya adalah membuat cerita dalam komik dengan sedemikian rupa disesuaikan dengan permasalahan-permasalahan yang muncul dalam kehidupan sehari-hari siswa. Hal ini dimaksudkan agar siswa sebagai pembaca merasa mengalami langsung peristiwa dan fenomena yang dialami tokoh dalam komik tersebut. Dengan demikian diharapkan komik mampu mengaitkan antara fakta dan konsep materi pelajaran rangka. Rangkaian plot cerita yang akan disusun menjadi prototype komik "KOMSA" terlebih dahulu disusun ke dalam storyboard untuk memudahkan dalam pengembangan cerita dan dialog dalam komik. Storyboard berisi sketsa gambar, latar cerita, narasi cerita, dan dialog/percakapan. Storyboard dijadikan sebagai pedoman dalam pengembangan cerita dan dialog dalam prototype komik "KOMSA" materi rangka.

\section{Fase Realization/Construction (Realisasi/Konstruksi)}

Storyboard yang telah dirancang pada fase design (desain), selanjutnya storyboard komik "KOMSA" materi rangka direalisasikan menjadi bentuk komik yang utuh dan lengkap. Prototype komik tersebut dibuat dalam beberapa tahap selama 3 bulan mulai dari membuat sketsa manual dengan pensil pada media kertas, scanning gambar manual, lalu 
hasil scan diolah dengan software Paint dan Photoshop. Prototype komik "KOMSA" materi rangka dicetak menjadi 16 halaman agar komik manjadi sangat handy untuk digunakan oleh siswa. Media komik ini didesain sebagai media visual yang tidak memerlukan sarana dan prasarana lain dalam penggunaannya.

Pada langkah pengerjaan yang lebih rumit untuk menghaluskan proses pengerjaan agar menjadi lebih enak dilihat dan lebih baik maka digunakan sebuah alat yaitu Graphic Tablet. Graphic Tablet adalah perangkat keras peranti masukan komputer yang membolehkan pemakainya untuk menggambar dengan tangan dan memasukkan gambar atau sketsa langsung ke komputer, layaknya menggambar di atas kertas menggunakan pensil (Belwal \& Belwal, 2018). Graphic Tablet yang digunakan dalam proses pewarnaan komik adalah Drawing Pad Wacom Intuos Pen N Touch Small CTH 480. Alat tersebut dipilih karena kemudahannya dalam menggunakan dan dapat menggambar dengan lebih detil dibandingkan dengan mengedit langsung dengan software Paint maupun Photoshop. Fase realisasi/konstruksi dilakukan selama 2 bulan dikerjakan oleh 3 peneliti. Hasil dari realisasi/konstruksi komik tersebut dibagi menjadi tiga bagian yaitu halaman cover, halaman pengenalan tokoh utama, dan halaman inti cerita komik. Contoh hasil dari realisasi/konstruksi pada halaman cover dapat dilihat pada GAMBAR 2 sedangkan halaman pengenalan tokoh dapat dilihat pada GAMBAR 3.

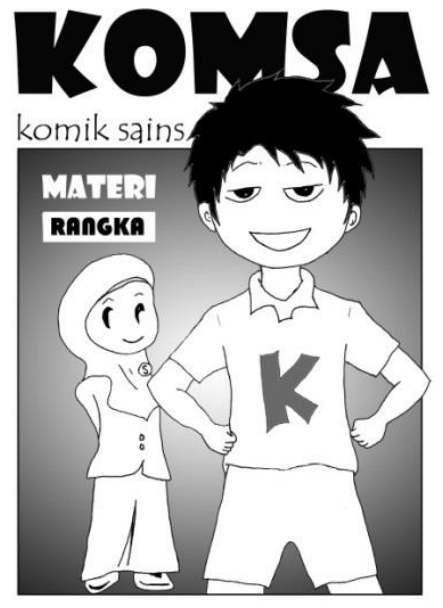

GAMBAR 2. Cover

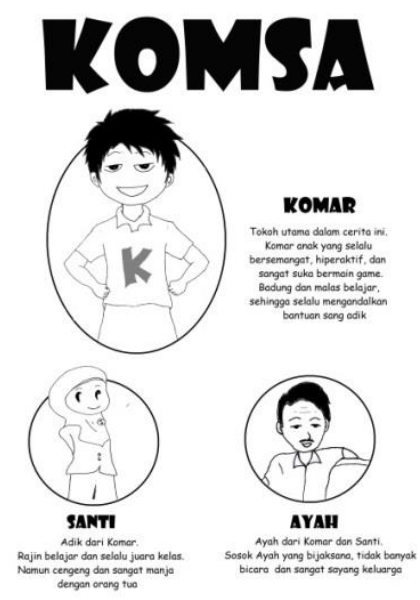

GAMBAR 3. Pengenalan Tokoh

Bagian inti komik terdiri dari 14 halaman dan menjadi bagian paling penting dalam komik secara keseluruhan karena bagian inilah yang berisi cerita komik yang kontekstual dan 
terintegrasi dengan materi rangka. Bagian inti ini dibagi menjadi bagian apersepsi rangka, bagian konsep susunan rangka tubuh manusia, bagian fungsi rangka, bagian penyakit rangka, dan bagian cara merawat rangka. Contoh halaman inti cerita dapat dilihat pada GAMBAR 4. Hasil komik tersebut kemudian akan dilanjutkan dalam fase berikutnya yaitu fase test, evaluation, dan revision pada tahun kedua untuk dilakukan uji validitas oleh ahli, uji kelayakan terbatas dan luas oleh siswa, uji efektivitas penggunaan komik di sekolah, dan revisi penyempurnaan komik tersebut.

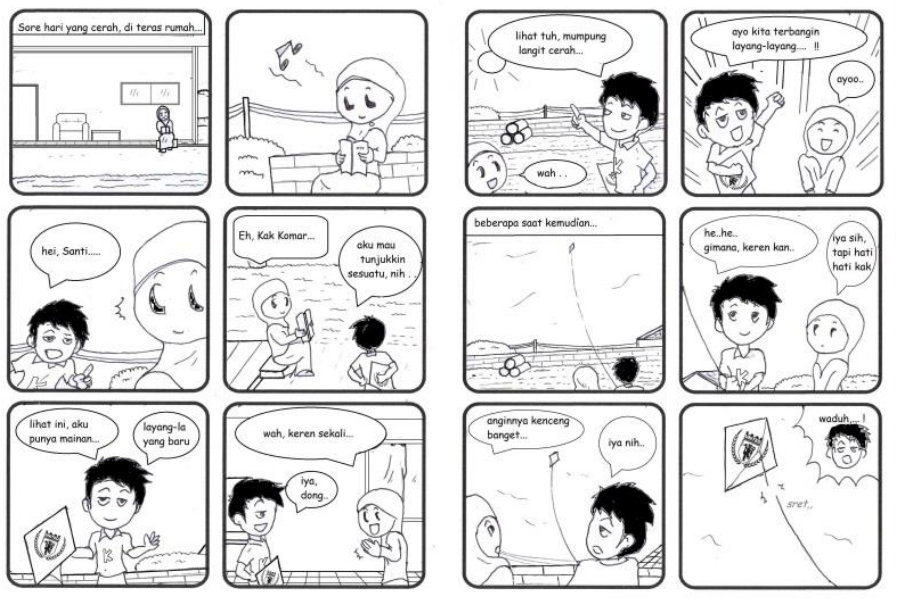

GAMBAR 4. Inti Cerita Komik

\section{PEMBAHASAN}

Pada fase preliminary investigation diperoleh bahwa untuk membuat pembelajaran menjadi tidak monoton dan membosankan, salah satu cara yang bisa digunakan adalah menyajikan materi dengan cara yang lebih menarik dan bermakna bagi siswa. Salah satu media yang cukup populer saat ini adalah komik (Hanif, 2011; Maflani, 2020). Komik selama ini digunakan sebagai media hiburan baik bagi anak-anak maupun orang dewasa. Selain itu komik memiliki potensi untuk dikembangkan menjadi media pembelajaran yang menarik bagi siswa. Komik memiliki kemudahan dalam penggunaan baik bagi guru maupun siswa serta mudah dalam pengaplikasiannya dalam mencapai tujuan pembelajaran yang ingin dicapai (Irwandani \& Juariyah, 2016; Prihanto \& Yunianta, 2018; Purwanto \& Yuliani, 2013).

Media komik penting untuk dikembangkan dalam pembelajaran IPA khususnya materi rangka di SD Negeri Pajang I Surakarta. Media komik merupakan salah satu media visual yang dapat menampilkan materi dengan lebih konkret, kontekstual, dan menarik bagi siswa sehingga siswa mudah dalam memahami materi pelajaran. Hal tersebut didukung pendapat Indra daulay et al. (2019) yang menyatakan bahwa rangsangan visual menimbulkan hasil belajar yang lebih baik untuk mengingat, mengenali, dan menghubungkan fakta dengan konsep. Pernyataan tersebut menunjukkan bahwa hasil belajar dapat menjadi lebih baik salah satunya dengan menghubungkan fakta dan konsep. Hal tersebut sangat terkait dengan kontekstual karena salah satu karakteristiknya adalah menghubungkan fakta dengan konsep (Setiyorini, 2018).

Pembelajaran kontekstual memanfaatkan aspek-aspek yang bersifat kontekstual yang terkait dengan kehidupan nyata pada topik yang sedang dibahas dalam sebuah proses pembelajaran (Afriani, 2018). Hal tersebut sejalan dengan Smith (2010) yang menyatakan pendekatan kontekstual didefinisikan sebagai konsepsi belajar mengajar yang membantu guru menghubungkan isi mata pelajaran dengan situasi dunia nyata. 
Keterkaitan antara fakta dan konsep tersebut dapat memudahkan siswa dalam memahami pembelajaran IPA (Pinwanna, 2015).

Media komik sebagai media pembelajaran dapat memberikan inovasi baru dalam pembelajaran IPA. Media komik tersebut dikembangkan dengan berbasis pada pendekatan kontekstual sehingga dapat menjadikan materi rangka yang abstrak dan sulit dipahami menjadi lebih konkret dan mudah dipahami siswa. Penggunaan komik sebagai media pembelajaran diharapkan dapat mengubah suasana pembelajaran menjadi lebih menarik, menyenangkan, dan tidak monoton sehingga siswa akan lebih cepat memahami pembelajaran IPA pada materi rangka. Dampak pengiring dari meningkatnya ketertarikan siswa dalam pembelajaran adalah dengan meningkatnya juga motivasi belajar dan minat belajar sehingga dapat berimbas pada peningkatan hasil belajar siswa (Puspitorini et al., 2014).

Dari fase investigasi awal diperoleh analisis kebutuhan dari pembelajaran IPA adalah terkait media pembelajaran IPA yang berbasis pendekatan kontekstual dalam bentuk komik. Pembuatan desain komik didasarkan dari pertimbangan-pertimbangan berikut ini (1) Komik merupakan bacaan yang populer dan sangat disukai siswa (Hanif, 2011; Maflani, 2020); (2) siswa sekolah dasar masuk dalam ranah operasional konkret sehingga lebih menyukai bacaan yang mengandung banyak gambar (Prayitno \& Faizah, 2019); (3) komik mampu menjadikan fenomena abstrak menjadi lebih konkret dengan rangsangan visual yang dihasilkan (Satria \& Sar, 2018); (4) komik mampu mengaitkan antara fakta dengan konsep yang dipelajari siswa (kontekstual) melalui cerita-cerita kehidupan sehari-hari yang disajikan (Afriani, 2018; Setiyorini, 2018); (5) peneliti memiliki keterampilan yang baik dalam menggambar komik dan mengedit gambar tersebut menggunakan aplikasi Paint, Paint Tool SAI, dan Photoshop (Wicaksono et al., 2017a).

Pada fase realisasi/konstruksi, media komik "KOMSA" materi rangka didesain dengan warna monokrom yaitu berupa hitam dan putih saja karena warna monokrom sangat sederhana, tidak banyak resiko, dan mudah diterima mata (Ariwibowo, 2019). Media komik ini didesain sebagai media visual yang tidak memerlukan sarana dan prasarana lain dalam penggunaannya. Media komik dapat dibaca kapanpun dan dimanapun siswa berada, termasuk digunakan untuk belajar sendiri oleh siswa di luar kelas maupun di dalam kelas bersama dengan guru (Wicaksono et al., 2017b).

\section{SIMPULAN}

Berdasarkan uraian hasil penelitian dan pembahasan dapat dikemukakan simpulan berkaitan dengan pengembangan media komik "KOMSA" materi rangka adalah (1) Hasil belajar IPA siswa masih rendah dikarenakan proses pembelajaran guru menggunakan buku teks maupun media yang masih sangat konvensional tanpa ada inovasi baru dan menarik bagi siswa; (2) telah dirancang media pembelajaran untuk membuat pembelajaran menjadi tidak monoton, membosankan, serta lebih inovatif dengan cara menyajikan materi lebih menarik dan bermakna bagi siswa dalam wujud media pembelajaran komik berbasis kontekstual yang mudah dipahami, digunakan, dan diterapkan oleh siswa; dan (3) pengembangan media pembelajaran komik "KOMSA" materi rangka pada tahun pertama dilakukan pada tiga fase utama yaitu: preliminary investigation, design, dan realization/ construction, untuk menghasilkan prototype/ purwarupa produk media pembelajaran komik "KOMSA" materi rangka.

Simpulan memberikan saran dan rekomendasi terkait hasil penelitian ini yaitu (1) peneliti selanjutnya dapat mengembangkan media komik "KOMSA" untuk materi pelajaran yang lain yang abstrak dan sulit dipahami oleh siswa; (2) guru sebaiknya menerapkan media komik "KOMSA" sebagai penunjang pembelajaran dalam kelas; dan (3) guru diharapkan turut menularkan penggunaan media komik dalam pembelajaran kepada guru-guru yang lain agar media komik dapat digunakan secara lebih luas; serta (4) siswa 
hendaknya membaca media komik "KOMSA" yang dikembangkan untuk meningkatkan hasil belajar kognitif pada materi rangka.

\section{DAFTAR PUSTAKA}

1. Afriani, A. (2018). Pembelajaran Kontekstual (Contextual Teaching and Learning) dan Pemahaman Konsep Siswa. Al Muta'aliyah STAI Darul Kamal NW Kembang Kerang, I(3), 80-88.

2. Ariwibowo, S. (2019). Perancangan Informasi Perkembangan Komik Daring Dengan Genre Drama Di Indonesia Di Tahun 2017-2018 Melalui Media Buku Komik. Universitas Komputer Indonesia.

3. Arsyad, A. (2011). Media Pembelajaran. PT. Raja Grafindo Persada.

4. Avrilliyanti, H., Budiawanti, S., \& Jam, J. (2013). Penerapan Media Komik Untuk Pembelajaran Fisika Model kooperatif Dengan Metode Diskusi Pada Siswa SMP Negeri 5 Surakarta kelas VII Tahun Ajaran 2011/2012 Materi Gerak. Jurnal Pendidikan Fisika, 1(1), 156-163.

5. Baharun, H. (2016). Pengembangan Media Pembelajaran Pai Berbasis Lingkungan Melalui Model ASSURE. Cendekia: Journal of Education and Society, 14(2), 231-246. https://doi.org/10.21154/cendekia.v14i2.610

6. Belwal, R., \& Belwal, S. (2018). Using the graphic tablet projection technology: improving students' learning through action research. International Journal of Technology Enhanced Learning, 10(4), 345-360. https://doi.org/10.1504/IJTEL.2018.095147

7. Chiappetta, E. L., \& Koballa, T. R. (2010). Science Instructional in The Middle and Secondary School 7th edition. Pearson/Allyn and Bacon.

8. Daryanto. (2013). Media Pembelajaran Peranannya sangat Penting dalam Mencapai Tujuan Pembelajaran. Gava Media.

9. Hadi, S., \& Novaliyosi. (2019). TIMSS Indonesia (Trends in International Mathematics and Science Study). Prosiding Seminar Nasional \& Call For Papers Program Studi Magister Pendidikan Matematika Universitas Siliwangi, 562-569.

10. Hanif, W. (2011). Komik Dewi Sartika Sebagai Media Pendidikan Sejarah Untuk Anak Smp Di Jawa Barat. ATRAT: Jurnal Seni Rupa, 4(3), 253-261.

11. Haryati, S. (2012). Research and Development (R\&D) Sebagai Salah Satu Model Penelitian dalam Bidang Pendidikan. Research And Development (R\&D) Sebagai Salah Satu Model Penelitian Dalam Bidang Pendidikan, 37(1), 11-26.

12. Hidayat, M. S. (2012). Pendekatan Kontekstual Dalam Pembelajaran. INSANIA: Jurnal Pemikiran Alternatif Kependidikan, 17(2) 231-247. https://doi.org/https://doi.org/10.24090/insania.v17i2

13. Indra daulay, M., Ananda, A., Anwar, S., \& Fatimah, S. (2019). Developing Comics-Based Social Sciences-History Teaching Materials. Proceedings of the 1st International Conference on Innovation in Education (ICoIE 2018), 178(ICoIE 2018), 77-83. https://doi.org/10.2991/icoie-18.2019.19

14. Irwandani, I., \& Juariyah, S. (2016). Pengembangan Media Pembelajaran Berupa Komik Fisika Berbantuan Sosial Media Instagram sebagai Alternatif Pembelajaran. Jurnal Ilmiah Pendidikan Fisika Al-Biruni, 5(1), 33-42. https://doi.org/10.24042/jpifalbiruni.v5i1.103

15. Kemdikbud, P. (2016). Hasil TIMSS 2015. Puspendik Kemdikbud.

16. Maflani, P. N. I. (2020). Maskulinitas Dan Feminitas Dalam Komik Digital Line Webtoon Indonesia Bergenre Fantasi. Universitas Airlangga.

17. Mahnun, N. (2012). Media Pembelajaran (Kajian terhadap Langkah-langkah Pemilihan Media dan Implementasinya dalam Pembelajaran). An-Nida', 37(1), 27-35.

18. Miftah, M. (2013). Fungsi, dan Peran Media Pembelajaran Sebagai Upaya Peningkatan Kemampuan Belajar Siswa. Kwangsan: Jurnal Teknologi Pendidikan, 1(2), 95-105. https://doi.org/10.31800/jtp.kw.v1n2.p95--105 
19. Negara, H. S. (2014). Penggunaan Komik Sebagai Media Pembelajaran Terhadap Upaya Meningkatkan Minat Matematika Siswa Sekolah Dasar (SD/MI). Jurnal Pendidikan Dan Pembelajaran Dasar, 1(2), 250-259.

20. Novianti, D. R., \& Syaichudin, M. (2015). Pengembangan Media Komik Matematika untuk Meningkatkan Pemahaman Bentuk Soal Cerita Bab Pecahan. Jurnal Teknologi Pendidikan, 10(1), 78-90.

21. Nugraheni, N. (2017). Penerapan Media Komik pada Pembelajaran Matematika di Sekolah Dasar. Refleksi Edukatika: Jurnal Ilmiah Kependidikan, 7(2) 111-117. https://doi.org/10.24176/re.v7i2.1587

22. Pinwanna, M. (2015). Using the Contextual Teaching and Learning Method in Mathematics to Enhance Learning Efficiency on Basic Statistics for High School Students. The International Conference on Language, Education, Humanities \& Innovation, 2010, 58-63.

23. Plomp, T., Akker, J. van den, Bannan, B., Kelly, A. E., \& Nieveen, N. (2013). Educational design research. In Handbook of Research on Educational Communications and Technology (Fourth Edi, pp. 1-207). Netherlands Institute for Curriculum Development (SLO). https://doi.org/10.1007/978-1-4614-3185-5_11

24. Pratiwi, W., \& Kurniawan, R. (2013). Penerapan Media Komik Sebagai Media Pembelajaran Ekonomi Di Sma Negeri 3 Ponorogo. Jurnal Pendidikan Ekonomi (JUPE), 1(3), 1-16.

25. Prayitno, S. H., \& Faizah, H. (2019). Pengembangan Media Pembelajaran untuk Materi FPB dan KPK bagi Siswa Sekolah Dasar Kelas IV. Jurnal Pendidikan Matematika, 7(3), 317-327.

26. Prihanto, D. A., \& Yunianta, T. N. H. (2018). Pengembangan Media Komik Matematika pada Materi Pecahan Untuk Siswa Kelas V Sekolah Dasar. Maju, 5(1), 79-90.

27. Purwanto, D., \& Yuliani. (2013). Pengembangan Media Komik IPA Terpadu Tema Pencemaran Air sebagai Media Pembelajaran untuk Siswa SMP Kelas VII. Jurnal Pendidikan Sains, 1(01), 71-76.

28. Puspitorini, R., Prodjosantoso, A. K., Subali, B., \& Jumadi, J. (2014). Penggunaan Media Komik dalam Pembelajaran IPA untuk Meningkatkan Motivasi dan Hasil Belajar Kognitif dan Afektif. Jurnal Cakrawala Pendidikan, 3(3), 413-420. https://doi.org/10.21831/cp.v3i3.2385

29. Ramdani, E. (2018). Model Pembelajaran Kontekstual Berbasis Kearifan Lokal sebagai Penguatan Pendidikan Karakter. JUPIIS: Jurnal Pendidikan Ilmu-Ilmu Sosial, 10(1), 110. https://doi.org/10.24114/jupiis.v10i1.8264

30. Sadiman, A. S. (2014). Educational media, understanding, development and utilization. Rajawali Press.

31. Satria, E., \& Sar, S. G. (2018). Penggunaan Alat Peraga Dan Kit Ipa Oleh Guru Dalam Pembelajaran Di Beberapa Sekolah Dasar Di Kecamatan Padang Utara Dan Nanggalo Kota Padang. Ikraith-Humaniora, 2(2), 1-8.

32. Setiyorini, N. D. (2018). Pembelajaran Kontekstual IPA Melalui Outdoor Learning di SD Alam Ar-Ridho Semarang. Journal AL-MUDARRIS, 1(1), 30-38. https://doi.org/10.32478/al-mudarris.v1i1.97

33. Smith, B. P. (2010). Instructional Strategies in Family and Consumer Sciences: Implementing the Contextual Teaching and Learning Pedagogical Model. Journal of Family \& Consumer Sciences Education, 28(1), 23-38.

34. Trisiana, A., Sutikno, A., \& Wicaksono, A. G. (2020). Media Digital Kartun Nilai Keslametriyadian (H. Wijayati (ed.)). UNISRI Press.

35. Wahyuningsih, A. N. (2012). Pengembangan Media Komik Bergambar Materi Sistem Saraf Untuk Pembelajaran Yang Menggunakan Strategi Pq4R. Journal of Innovative Science Education, 1(1), 19-27.

36. Wicaksono, A. G. (2020). Penyelenggaraan Pembelajaran IPA Berbasis Pendekatan STEM dalam Menyongsong Era Revolusi Industri 4.0. LENSA (Lentera Sains): Jurnal Pendidikan IPA, 10(1), 54-62. https://doi.org/10.24929/lensa.v10i1.98 
37. Wicaksono, A. G., Irmade, 0., \& Jumanto. (2017a). Pengembangan Media Komik "KOMSA" Berbasis Kontekstual pada Pembelajaran Sains di SD. Prosiding Seminar Nasional Pendidikan IPA IX 2017: TPACK Optimalisasi Pemanfaatan ICT Untuk Meningkatkan Profesionalisme Guru Dalam Pembelajaran IPA Di Era Digital, 23-30.

38. Wicaksono, A. G., Irmade, 0., \& Jumanto, J. (2017b). Efektifitas Penggunaan Media Komik KOMSA Berbasis Kontekstual dalam Pembelajaran Sains di SD. Prosiding Seminar Nasional Pendidikan IPA 2017, 2, 609-614.

39. Widyawati, A., \& Prodjosantoso, A. K. (2015). Pengembangan Media Komik IPA untuk Meningkatkan Motivasi Belajar dan Karakter Peserta Didik SMP. Jurnal Inovasi Pendidikan IPA, 1(1), 24-35. https://doi.org/10.21831/jipi.v1i1.4529

\section{PROFIL SINGKAT}

Anggit Grahito Wicaksono adalah dosen program studi pendidikan guru sekolah dasar, fakultas keguruan dan ilmu pendidikan, Universitas Slamet Riyadi Surakarta. Ia juga merupakan sekretaris Program Studi Pendidikan Guru Sekolah Dasar, Fakultas Keguruan dan Ilmu Pendidikan, Universitas Slamet Riyadi Surakarta. Selain itu ia aktif dalam proyek penelitian pada bidang Pendidikan dan Pembelajaran IPA.

Jumanto adalah dosen Program Studi Pendidikan Guru Sekolah Dasar, Fakultas Keguruan dan Ilmu Pendidikan, Universitas Slamet Riyadi Surakarta. Ia juga merupakan ketua Program Studi Pendidikan Guru Sekolah Dasar, Fakultas Keguruan dan Ilmu Pendidikan, Universitas Slamet Riyadi Surakarta. Selain itu ia aktif dalam proyek penelitian pada bidang Pendidikan Dasar.

Oka Irmade adalah dosen Program Studi Pendidikan Guru Pendidikan Anak Usia Dini, Fakultas Keguruan dan Ilmu Pendidikan, Universitas Slamet Riyadi Surakarta. Ia juga merupakan asesor akreditasi dari BAN-PAUD. Selain itu ia aktif dalam projek penelitian pada bidang Teknologi Pendidikan dan Pembelajaran. 